\title{
Effect of Personal Protective Equipment during Pesticide Application to Neurological Symptoms in Farmers in Purworejo District, Indonesia
}

\author{
Pengaruh Alat Pelindung Diri selama Pengaplikasian Pestisida terhadap \\ Gejala Kelainan Saraf pada Petani di Kabupaten Purworejo, Indonesia
}

Fajaria Nurcandra*, Renti Mahkota**, Siddharudha Shivalli****

*Public Health Studies, Faculty of Health Sciences, Universitas Pembangunan Nasional Veteran Jakarta, Depok, Indonesia, **Department of Epidemiology, Faculty of Public Health, Universitas Indonesia, Depok, Indonesia, ***Faculty of Public Health, Yanepoya University, Karnataka, India

\begin{abstract}
Agriculture is one of major sectors of Indonesia economic source with the high volume of pesticide used. Unfortunately, adverse health effect of neurotoxic pesticide has never been reported in Indonesia. This study aimed to determine effectiveness of personal protective equipment (PPE) during the use of pesticides to neurological symptoms in farmers. This study was cross-sectionally conducted from April to May 2016 in Purworejo District. About 125 farmers were selected using purposive sampling, and restriction was applied in male farmers due to the high proportion of male sprayer. Data was collected by observation and interview. Logistic regression showed protective result of PPE used during preparing ( $P O R=0.40 ; 95 \% \mathrm{Cl}=0.11-1.42)$ and spraying $(\mathrm{POR}=0.38$; $95 \% \mathrm{Cl}=0.11-1.32$ ), also following wind direction $(\mathrm{POR}=0.88 ; 95 \% \mathrm{Cl}=0.27-2.87$ ) and bathing after spraying $(\mathrm{POR}=0.33 ; 95 \% \mathrm{Cl}=0.04-3.01)$ after controlled by confounders. Proper PPE used during preparing and spraying pesticide, following wind direction during spraying, and bathing after spraying can decrease risk of neurological symptoms because of pesticide exposure.

Keywords: Neurological symptoms, personal protective equipment, pesticide

Abstrak

Pertanian merupakan salah satu sektor utama sumber ekonomi Indonesia dengan tingginya volume pestisida yang digunakan. Sayangnya, dampak kesehatan yang buruk dari pestisida yang bersifat neurotoksik selama ini tidak pernah dilaporkan di Indonesia. Penelitian ini bertujuan untuk menganalisis efektivitas proteksi alat pelindung diri (APD) selama penggunaan pestisida terhadap gejala kelainan saraf pada petani. Penelitian ini dilakukan secara potong lintang di Purworejo selama April-Mei 2016. Sejumlah 125 petani dipilih dengan menggunakan purposive sampling dan restriksi dilakukan pada petani lakilaki karena tingginya proporsi petani laki-laki penyemprot. Data dikumpulkan dengan cara observasi dan wawancara. Regresi logistik menunjukkan efek proteksi penggunaan $\mathrm{APD}$ yang digunakan selama penyiapan $\mathrm{POR}=0.40 ; 95 \% \mathrm{Cl}=0.11-1.42)$ dan penyemprotan $(\mathrm{POR}=0.382 ; 95 \% \mathrm{Cl}=0.11-1.32)$, serta penyemprotan searah angin $(P O R=0.88 ; 95 \% \mathrm{Cl}=0.27-2.87)$ dan mandi setelah penyemprotan $(\mathrm{POR}=0.33 ; 95 \% \mathrm{Cl}=0.04-3.01)$ setelah dikontrol dengan variabel perancu. Penggunaan APD selama penyiapan dan penyemprotan pestisida, penyemprotan searah arah angin, dan mandi setelah penyemprotan dapat menurunkan risiko gejala kelainan saraf akibat pajanan pestisida.
\end{abstract}

Kata kunci: Gejala kelainan saraf, proteksi alat pelindung diri, pestisida

How to Cite: Nurcandra F, Mahkota R, Shivalli S. Effect of personal protective equipment during pesticide application to neurological symptoms in farmers in Purworejo District, Indonesia. Kesmas: National Public Health Journal. 2018; 12 (4): 165-171. (doi:10.21109/kesmas.v12i4.1695)
Correspondence: Fajaria Nurcandra, Faculty of Health Sciences, Universitas Pembangunan Nasional Veteran Jakarta, Limo Raya Street, Depok, Phone: +6221-7532884, E-mail: fnurcandra@gmail.com

Received: August 29th 2017

Revised: January $2^{\text {nd }} 2018$

Accepted: January $15^{\text {th }} 2018$ 


\section{Introduction}

About 1.8 billion people use pesticide extensively in agricultural site to protect food and other commercial products worldwide. Over 5.6 billion pounds of pesticide are used worldwide. However, programs to control pesticide exposure are limited, which causes over 25 million farmers worldwide experience unintentional pesticide poisonings each year. ${ }^{1}$ Acute and chronic high level of exposure to neurotoxic pesticide have been reported from organophosphate, carbamate, organochlorine, and pyrethroid insecticides, herbicides, fungicides, and fumigants. ${ }^{2}$

Symptoms in Indonesian pesticide sprayers were reported with the most frequent symptoms being fatigue, muscle stiffness, dry throat, muscle weakness, dizziness, difficulty in breathing, and chest pain. ${ }^{3}$ A study in Brebes, Central Java reported that symptoms of neurological symptoms in farmers appeared possibly related to pesticide exposure. ${ }^{4}$

Neurological symptoms caused by pesticide exposure are often identified as Parkinson's disease symptoms. These symptoms are rigidity, rest tremor, bradykinesia, impairment of postural reflexes, degradation of cognitive, motor, and sensory dysfunction. ${ }^{2,5}$ Most studies showed relation between symptom of Parkinson's disease and cumulative lifetime exposure to pesticides especially in cognitive and psychomotor. ${ }^{1,2,5,6}$ Previous studies also found that moderate to chronic exposure increased risk of representation of neurological symptoms. Cognition, motor, sensory, and autonomic function may represent neurological symptoms as early evidence of neurological symptoms before clinical signs. ${ }^{2,5}$

Dermal is known as the major route of pesticide exposure during handling. The use of personal protective equipment (PPE) during application procedures, packaging, mixing is to reduce risk of adverse effect of pesticide exposure. Cholinesterase activity and urinary metabolites as biomonitoring can identify high risk of exposure level. ${ }^{7,8}$ The non-use of PPE indicated significant into higher percentage of acetyl cholinesterase (AChE) activity inhibition than those who used PPE. ${ }^{9}$

A predictive study in Majalengka, West Java also found part of protective equipment (the non-use of long sleeve self-protective wear) and bad personal hygiene aspect (proper shower) influenced cholinesterase activity beside spraying records, smoking during spraying, records of training/extension, spraying position against wind, and age. ${ }^{10}$ Pesticide exposure effect to cholinesterase enzyme activity using restriction among fertile women in Brebes showed a significant relation between pesticide types, working time, the use of gloves, and hand-washing behavior. ${ }^{11}$ Previous study found that majority of pesticide users were not using protective gears and not following recommended safety measures. ${ }^{8}$ Cezar-
Vaz et al., 12 reported the use of PPE in Brazil in which most of individuals did not make use of PPE, while the improper use of PPE may aggravate their exposure.

This study was conducted in Purworejo District, Central Java as it included rural residence with population of 2,500 people or less. ${ }^{13}$ Besides, Purworejo is known as the largest plantation area in Indonesia that is possible of pesticide used in a high volume for the plant protection. ${ }^{14}$ However, farmers actually had experienced occupational pesticide poisoning, but this case has never been reported by the local government. ${ }^{15}$ This study did not attempt to distinguish other neurological diseases which can be caused by various non-agricultural chemicals or as a disability effect of Alzheimer's disease or stroke. This study aimed to examine effectiveness of PPE in reducing risk of neurological symptoms in farmers.

\section{Method}

Purworejo residents were enrolled in this cross-sectional study between April-May 2016. About 125 samples were recruited without knowing exposure or disease status. This study applied restriction in male farmers because of the high propotion of male sprayers. Informed consent was obtained from each participant first for completion of self-administered questionnaire. ${ }^{16}$ Samples were interviewed about neurological symptoms, PPE used, length of farming, working period, pesticide quantity, personal hygiene, rice field area, age, body mass index (BMI), education, monthly income. Previous studies found chronic effect of pesticide exposure to neurological symptoms. 2,5,6 Hence, samples were farmers aged between 40-75 years old because the study analyzed chronic exposure or long-term exposure.

Questionnaire was modified from previous studies to evaluate neurological symptoms. ${ }^{2,4}$ Data collectors were blinded for hypothesis of this study. The study compared farmers between those who had experienced more than 10 of 22 symptoms (case) and those who had experienced less than 10 symptoms (non-case). Then the study categorized the symptoms representing neurological functions into feeling or emotion, cognitive, sensory, motor, autonomic, and other symptoms based on previous studies. 2,4 PPE was divided into complete and incomplete PPE. Complete PPE is defined if farmer had used mask, long clothes, and gloves during preparing pesticide, while complete PPE during spraying is defined if farmer had used mask, long clothes, gloves, and head cover.

This study applied univariate and multivariate logistic regression analysis. The relative risk of independent variables was estimated by prevalence odds ratio (POR). The precision of the POR was pointed by $95 \% \mathrm{CI}$ and $\mathrm{p}$ value $<0.05$ was defined as statistical significance. Other variables were noted as confounding, and retained if a 
change of POR $>10 \%$. Those variables were controlled in multivariate regression models.

\section{Results}

All farmers (100\%) did not use goggles or protection equipment for their eyes. As much as $20 \%$ of farmers answered they smell pesticide even though they wore mask. Most respondents had good personal hygiene. Questionnaire-based information on neurological symptoms were used to evaluate the occupational effects of pesticide exposure. Organophosphate was most widely used by farmers. There were eight farmers who used insecticide diazinon without knowing that it was banned. Type of pesticide used was asked using the trade name. The study evaluated the symptoms among farmers who had experienced 10 or more in last one year.

All of the main independent variables showed protective effect to neurological symptoms. The proportion of complete PPE used during preparing step was higher at both neurological symptom group and non-neurological symptom group. Similar proportion was shown in PPE used during spraying, which was higher in complete PPE among neurological symptoms group and non-neurological symptoms group. Hygiene behavior remained high of having bathing behavior after spraying at group with no neurological symptoms than at group with neurological symptoms. There was a high proportion of farmers who followed wind direction during spraying at group with no neurological symptoms.
The study analyzed monthly income and land area to capture economic status of the subjects. The high proportion was found in group with income less than IDR 750,000 /per month or about \$57 USD/per month both in neurological symptom group and non-neurological symptom group. Area of pesticide-sprayed paddy field was found higher in the area of greater than $20,000 \mathrm{~m}^{2}$. The high proportion was found at group with land area ownership $20,000 \mathrm{~m}^{2}$ that had no neurological symptoms. Low and moderate level of smoking behavior were dominant. This study found no differences in BMI proportion between group with and without neurological symptoms. Because the collected data came from old subjects, the high proportion was the age older than 58 years.

Analysis on PPE used during preparing pesticide toward neurological symptoms after controlled by confounders showed adjusted POR as protective effect (POR $=0.40 ; 95 \% \mathrm{CI}=0.11-1.42$ ) (Table 2 ). It means that farmers who used complete PPE (mask and gloves) during preparing pesticide were 2.49 times less likely to suffer from neurological symptoms. Extragenous variables were examined with the change of POR more than $10 \%$. Working period, rice field area, monthly income, education level, age, and personal hygiene were the confounders.

Analysis of PPE used during spraying to neurological symptoms after controlled by the confounders showed adjusted $\mathrm{POR}$ as protective effect $(\mathrm{POR}=0.38 ; 95 \% \mathrm{CI}=$ 0.11-1.32) (Table 3). It means that farmers who used

Table 1. Results of Bivariate Analysis on Independent Variables and Extragenous Variables to Neurological Symptoms

\begin{tabular}{|c|c|c|c|c|c|c|c|c|c|}
\hline \multirow[b]{2}{*}{ Variable } & \multirow[b]{2}{*}{ Category } & \multicolumn{4}{|c|}{ Neurological Symptoms } & \multirow[b]{2}{*}{ POR } & & & \multirow[b]{2}{*}{ p Value } \\
\hline & & \multicolumn{2}{|c|}{ Yes } & \multicolumn{2}{|c|}{ No } & & \multicolumn{2}{|c|}{ 95\% CI } & \\
\hline PPE used during preparing & Complete & 9 & 56.2 & 85 & 77.98 & 0.36 & 0.11 & 1.29 & 0.060 \\
\hline PPE used during spraying & Incomplete & 7 & 43.8 & 22 & 20.2 & 0.32 & 0.10 & 1.16 & 0.037 \\
\hline \multirow[t]{2}{*}{ Bathing after spraying } & Yes & 1 & 6.2 & 15 & 13.8 & \multirow[t]{2}{*}{0.42} & \multirow[t]{2}{*}{0.01} & \multirow[t]{2}{*}{3.15} & \multirow[t]{2}{*}{0.401} \\
\hline & No & 15 & 93.8 & 94 & 86.2 & & & & \\
\hline \multirow[t]{2}{*}{ Following wind direction } & Yes & 6 & 37.5 & 47 & 43.1 & \multirow[t]{2}{*}{0.79} & \multirow[t]{2}{*}{0.22} & \multirow[t]{2}{*}{2.61} & \multirow[t]{2}{*}{0.671} \\
\hline & No & 10 & 62.5 & 62 & 56.9 & & & & \\
\hline Monthly income & $<$ IDR 750,000 & 13 & 81.2 & 55 & 50.5 & 4.25 & 1.07 & 24.31 & 0.020 \\
\hline Smoking behavior & High & 4 & 25.0 & 13 & 11.9 & 2.46 & 0.50 & 9.77 & 0.154 \\
\hline & Low-moderate & 12 & 75.0 & 96 & 88.1 & & & & \\
\hline Body mass index & $<20.31$ & 8 & 50.0 & 58 & 53.2 & 0.88 & 0.27 & 2.91 & 0.810 \\
\hline & 20.31 & 8 & 50.0 & 51 & 46.8 & & & & \\
\hline Age & 58 years old & 10 & 62.5 & 55 & 50.5 & 1.64 & 0.50 & 5.86 & 0.368 \\
\hline & $>58$ years old & 6 & 37.5 & 54 & 49.5 & & & & \\
\hline Land area & $20,000 \mathrm{~m}^{2}$ & 7 & 43.8 & 93 & 85.3 & 0.13 & 0.04 & 0.48 & 0.0001 \\
\hline & $<20,000 \mathrm{~m}^{2}$ & 9 & 56.8 & 16 & 14.7 & & & & \\
\hline
\end{tabular}

Notes:

$\mathrm{n}=$ Number of Sample, $\%=$ Percentage, $\mathrm{POR}=$ Prevalence Odds Ratio, $\mathrm{PPE}=$ Personal Protective Equipment 
Table 2. PPE Used during Preparing Pesticide toward Neurological Symptoms

\begin{tabular}{|c|c|c|c|c|c|c|}
\hline \multirow{2}{*}{ Variable } & \multirow{2}{*}{ Category } & \multirow{2}{*}{$\beta$} & \multirow{2}{*}{ SE } & \multirow{2}{*}{$\begin{array}{l}\text { Adjusted } \\
\text { POR }\end{array}$} & \multicolumn{2}{|c|}{ 95\% CI } \\
\hline & & & & & Lower & Upper \\
\hline \multirow[t]{2}{*}{ PPE used during preparing } & Complete & -0.91 & 0.64 & 0.40 & 0.11 & 1.42 \\
\hline & Incomplete & Ref & & & & \\
\hline \multirow[t]{2}{*}{ Pesticide quantity } & 26 liter/year & -0.58 & 0.69 & 0.56 & 0.14 & 2.16 \\
\hline & $<26$ liter/year & Ref & & & & \\
\hline \multirow[t]{2}{*}{ Working period } & 11 years & 0.69 & 1.11 & 1.98 & 0.22 & 17.46 \\
\hline & $<11$ years & Ref & & & & \\
\hline \multirow[t]{2}{*}{ Education level } & $<$ Middle school & -0.58 & 0.60 & 0.56 & 0.17 & 1.83 \\
\hline & Middle school & Ref & & & & \\
\hline \multirow[t]{2}{*}{ Monthly income } & $<$ IDR 750,000 & 1.56 & 0.70 & 4.78 & 1.22 & 18.70 \\
\hline & IDR 750,000 & Ref & & & & \\
\hline
\end{tabular}

Notes:

$\mathrm{SE}=$ Standard Error, $\mathrm{POR}=$ Prevalence Odds Ratio, $\mathrm{CI}=$ Confidence Interval, $\mathrm{PPE}=$ Personal Protective Equipment

Table 3. PPE Used during Spraying Pesticide toward Neurological Symptoms

\begin{tabular}{|c|c|c|c|c|c|c|}
\hline \multirow{2}{*}{ Variable } & \multirow{2}{*}{ Category } & \multirow{2}{*}{$\beta$} & \multirow{2}{*}{$\mathrm{SE}$} & \multirow{2}{*}{$\begin{array}{l}\text { Adjusted } \\
\text { POR }\end{array}$} & \multicolumn{2}{|c|}{$95 \% \mathrm{CI}$} \\
\hline & & & & & Lower & Upper \\
\hline PPE used during spraying & $\begin{array}{l}\text { Complete } \\
\text { Incomplete }\end{array}$ & $\begin{array}{l}-0.96 \\
\text { Ref }\end{array}$ & 0.63 & 0.38 & 0.11 & 1.32 \\
\hline Pesticide quantity & $\begin{array}{c}26 \text { liter/year } \\
<26 \text { liter/year }\end{array}$ & $\begin{array}{l}-0.55 \\
\text { Ref }\end{array}$ & 0.68 & 0.58 & 0.15 & 2.18 \\
\hline Education level & $\begin{array}{c}<\text { Middle school } \\
\text { Middle school }\end{array}$ & $\begin{array}{l}-0.56 \\
\text { Ref }\end{array}$ & 0.60 & 0.57 & 0.18 & 1.86 \\
\hline Monthly income & $\begin{array}{c}<\text { IDR } 750,000 \\
\text { IDR } 750,000\end{array}$ & $\begin{array}{l}1.55 \\
\text { Ref }\end{array}$ & 0.70 & 4.72 & 0.12 & 18.54 \\
\hline
\end{tabular}

Notes:

$\mathrm{SE}=$ Standard Error, $\mathrm{POR}=$ Prevalence Odds Ratio, $\mathrm{CI}=$ Confidence Interval, $\mathrm{PPE}=$ Personal Protective Equipment

Table 4. Bathing after Spraying toward Neurological Symptoms

\begin{tabular}{|c|c|c|c|c|c|c|}
\hline \multirow{2}{*}{ Variable } & \multirow{2}{*}{ Category } & \multirow{2}{*}{$\beta$} & \multirow{2}{*}{ SE } & \multirow{2}{*}{$\begin{array}{l}\text { Adjusted } \\
\text { POR }\end{array}$} & \multicolumn{2}{|c|}{$95 \% \mathrm{CI}$} \\
\hline & & & & & Lower & Upper \\
\hline Bathing after spraying & $\begin{array}{r}\text { Yes } \\
\text { No }\end{array}$ & $\begin{array}{l}-1.12 \\
\text { Ref }\end{array}$ & 1.13 & 0.33 & 0.04 & 3.01 \\
\hline Monthly income & $\begin{array}{c}<\text { IDR } 750,000 \\
\text { IDR } 750,000\end{array}$ & $\begin{array}{l}1.19 \\
\text { Ref }\end{array}$ & 0.70 & 3.30 & 0.83 & 13.02 \\
\hline Land area & $\begin{array}{c}20,000 \mathrm{~m}^{2} \\
<20,000 \mathrm{~m}^{2}\end{array}$ & $\begin{array}{l}-1.82 \\
\text { Ref }\end{array}$ & 0.59 & 0.16 & 0.05 & 0.52 \\
\hline
\end{tabular}

Notes:

$\mathrm{SE}=$ Standard Error, $\mathrm{POR}=$ Prevalence Odds Ratio, $\mathrm{CI}=$ Confidenece Interval, $\mathrm{PPE}=$ Personal Protective Equipment

complete PPE (mask, long clothes, head cover) during preparing pesticide were 3.049 times less likely to suffer from neurological symptoms. Extragenous variables were examined with the change of POR more than $10 \%$. Pesticide quantity, education level and monthly income were found as confounders. Based on the interview about uncompliance of PPE used, the study found that the major reason of incomplete PPE during spraying wasincon- venience (difficulty to move around mud of rice field and the high temperature of weather).

Analysis of bathing after spraying to neurological symptoms after controlled by confounders showed adjusted $\mathrm{POR}$ as protective effect $(\mathrm{POR}=0.33 ; 95 \% \mathrm{CI}=$ 0.04-3.01) (Table 4). It means that farmers who used complete PPE (mask, long clothes, head cover) during preparing pesticide were 3.049 times less likely to suffer 
Table 5. Following Wind Direction to Neurological Symptoms

\begin{tabular}{|c|c|c|c|c|c|c|}
\hline \multirow{2}{*}{ Variable } & \multirow{2}{*}{ Category } & \multirow{2}{*}{$\beta$} & \multirow{2}{*}{ SE } & \multirow{2}{*}{$\begin{array}{c}\text { Adjusted } \\
\text { POR }\end{array}$} & \multicolumn{2}{|c|}{$95 \% \mathrm{CI}$} \\
\hline & & & & & Lower & Upper \\
\hline \multirow[t]{2}{*}{ Following wind direction } & Yes & -0.12 & 0.60 & 0.88 & 0.27 & 2.87 \\
\hline & No & Ref & & & & \\
\hline \multirow[t]{2}{*}{ Pesticide quantity } & 26 liter/year & -0.91 & 0.64 & 0.40 & 0.11 & 1.42 \\
\hline & $<26$ liter/year & Ref & & & & \\
\hline \multirow[t]{2}{*}{ Land area } & $20,000 \mathrm{~m}^{2}$ & -1.96 & 0.58 & 0.14 & 0.04 & 0.44 \\
\hline & $<20,000 \mathrm{~m}^{2}$ & Ref & & & & \\
\hline
\end{tabular}

Notes:

$\mathrm{SE}=$ Standard Error, $\mathrm{POR}=$ Prevalence Odds Ratio, $\mathrm{CI}=$ Confidence Interval, $\mathrm{PPE}=$ Personal

Protective Equipment

from neurological symptoms. The study found that monthly income and land area were confounders because POR changed more than $10 \%$.

Analysis of following wind direction toward neurological symptoms after controlled by confounders showed adjusted $\mathrm{POR}$ as protective effect $(\mathrm{POR}=0.88$; $95 \% \mathrm{CI}=0.27-2.87$ ) (Table 5). It means that farmers who used complete PPE (mask, long clothes, head cover) during preparing pesticide were 1.134 times less likelyto suffer from neurological symptoms. The study found that pesticide quantity and land area were confounders with the change of POR more than $10 \%$.

\section{Discussion}

Neurological symptoms, as symptoms of Parkinson's disease before the clinical sign may be associated with long-term exposure to pesticide without identified type of pesticide. ${ }^{5}$ Although further analysis was not done to distinguish exposure level and age specific to low proportion of neurological symptoms, but this study argued that the low proportion of neurological symptoms was because of good personal hygiene and PPE used behavior during handling pesticide. ${ }^{17}$ Occupational pesticide exposure was associated with Parkinson's Disease. 1,2,5,6,18,19 Wright and Kellerfound, 16 found no association between occupational and residential pesticide use with Parkinson's disease.

This study showed the high proportion of PPE use which was already good, but all repondents did not use goggles and good personal hygiene because they were traditional farmers. However, the proportion was different with PPE porportion in study by Lekei et al.,. ${ }^{20}$ While an exploratory study in pesticide shop keepers by Kesavachandran et al., 17 in India found that pesticide handlers were risked to the exposure through ingestion, inhalation and dermal. Non-use of PPE by those shop keepers was attributed to poor enforcement. ${ }^{17}$ Fareed et al., ${ }^{21}$ found the adverse health effect of unsafe pesticide handling in North India. The non-use of PPE like safety masks, gloves, etc during the spraying especially in farmers can adversely affect hematological alterations and change the acetyl cholinesterase (AchE) activity. This is in contrast to most studies which reported that pesticide handlers were unaware of importance of the use of PPE such as head cover, long clothes, apron, gloves, masks and long boots during handling, mixing and spraying of pesticides.10,21,22 Furthermore, the study found that farmers mixed pesticide by using their bare hands. Only a few persons took precautions even though they knew that the use of protective equipment can protect the body from the adverse health effects of pesticides. ${ }^{9}$

Farmers were potentially exposed to pesticide and suffering from Parkinson disease later in life. The study found that many farmers spraying pesticide did not follow right direction. The proportion was a little bit higher than in the study by Singh et al., 8 in India.

All previous studies had the same result with this study. ${ }^{21,22}$ About $80 \%$ of farmers of this study used complete PPE during mixing and spraying pesticide. LaVerda, ${ }^{23}$ stated in her study that the use of PPE (i.e., gloves, respirators, face shields, boots, overalls, etc.) affects the level of pesticide exposure besides the type of activity, the method of application, pesticide formulation, application rate, personal habits, and cleanliness and frequency of health care visits. Previous study in a rural area in Indonesia among farmers who applied pesticides (dithiocarbamates, pyrethroids and organophosphates) reported that farmers who wore no mask/respirator, wet clothing or short-sleeves, had greater skin contact with pesticides, and those who smoked during spraying had higher risk of increasing health problems. ${ }^{24}$ Those studies supported this study that found protective effect of PPE used. Different with this study, a previous study on pesticide exposure effect to decreasing cholinesterase activity showed long sleeve self-protective wear used and proper shower as risk factors. 10

There were more than $50 \%$ of respondents who had monthly income under IDR 750,000 and this rate was 
below the regional minimum income. Hence, farmers who did not use PPE had poor socio-economic status, even though they understand the toxicity of pesticides. This finding was in line with the finding of study by Pathak et al.,22 Farmers were potentially exposed to pesticide and suffering from Parkinson disease later in life.

If misclassification bias existed, it led to non-differential misclassification and no effect on external validity of this study. Non-differential misclassification might exist in classification/categorization of neurological symptoms, PPE, personal hygiene behavior, spraying behavior and covariate variables. Following previous study, the symptoms were presented with only slight or mild signs. ${ }^{5}$ This study was limited in which variables were categorized into two strata which means insensitive to show risk or role of each strata to neurological symptoms. The study did not examine other chemical exposures or childhood exposure. Unfortunately, the chance existed because $95 \%$ CI passed null value. It might be caused by unmeasured variables, residual confounding, non-sensitive measurement or classification in this study. Residual confounding by unmeasured or poor measurement covariates is another limitation of this study, such as material of PPE, type of each PPE, knowledge of the harmful pesticide, pesticide container, application method, etc. 8,16

\section{Conclusion}

In conclusion, PPE used is strong protector of neurotoxic pesticide effect. It is supported by the good behavior of personal hygiene. Organophosphate is most commonly used by farmers. Neurological symptoms may be associated to cumulative pesticide exposure in long-term exposure. This study suggests the local government to introduce awareness programs on pesticide toxicity levels, to provide workshop for handling pesticides, and free distribution of PPE through government/non-governmental organizations to pesticide sprayers.

\section{References}

1. Alavanja MCR. Pesticides use and exposure extensive worldwide. Reviews on Environtal Health [Internet]. 2009; 24 (4): 303-9. Available from: http://www.degruyter.com/view/j/reveh.2009.24.4/reveh. 2009.24.4.303/reveh.2009.24.4.303.xml

2. Kamel F, Engel LS, Gladen BC, Hoppin JA, Alavanja MCR, Sandler DP. Neurologic symptoms in licensed pesticide applicators in the Agricultural Health Study. Human and Experimental Toxicology [Internet]. 2007; 26 (3): 243-50. Available from: http://www.ncbi. nlm.nih.gov/pubmed/17439927

3. Kishi M, Hirschhorn N, Djajadisastra M, Satterlee LN, Strowman S DR. Relationship of pesticide spraying to signs and symptoms in Indonesian farmers. Scandinavian Journal of Work, Environment \& Health. 1995; 21 (2): 124-33.

4. Hermawati E. Evaluation of nurological disorders in agricultural work- ers at Brebes District Central Java, 2014. In: APACPH Conference Bandung, 21-23 October 2015. 2015. p. 21-3.

5. Engel LS, Checkoway H, Keifer MC, Seixas NS, Longstreth WT, Scott $\mathrm{KC}$, et al.Parkinsonism and occupational exposure to pesticides. Occupational and Environment Medicine. 2001; 58 (9): 582-9.

6. Hancock DB, Martin ER, Mayhew GM, Stajich JM, Jewett R, Stacy MA, et al. Pesticide exposure and risk of Parkinson â $\mathrm{TM}_{\mathrm{S}}$ disease?: A family-based case-control study. Scandinavian Journal of Work, Environment \& Health. 2011; 37 (5): 427-36.

7. Ismail AA, Bonner MR, Hendy O, Rasoul GA, Wang K, Olson JR, et al. Comparison of neurological health outcomes between two adolescent cohorts exposed to pesticides in Egypt. PLoS One. 2017; 12 (2): 1-14.

8. Singh B, Gupta MK. Pattern of use of personal protective equipments and measures during application of pesticides by agricultural workers in a rural area of Ahmednagar district, India. Indian Journal of occupational and Environmental Medicine. 2009; 13 (3): 127-30.

9. Jintana S, Sming K, Krongtong Y, Thanyachai S. Cholinesterase activity, pesticide exposure and health impact in a population exposed to organophosphates. International Archives of Occupational and Environmental Health. 2009; 82 (7): 833-42.

10. Ruhendi D. Faktor determinan aktivitas kholinesterase darah petani holtikultura di Kabupaten Majalengka. Jurnal Kesehatan Masyarakat Nasional. 2008; 2 (5): 215-9.

11. Rahman DA, Zakianis, Fitria L. Pesticide exposure, behavior of farmer, and activity of cholinesterase enzyme in blood of fertile women farmers. Kesmas: Jurnal Kesehatan Masyarakat Nasional, 2015; 10 (2): 51-6.

12. Cezar-Vaz MR, Bonow CA, Mello MCVA de, SilvaI MRS da. Socio-environmental approach in nursing?: focusing on rural labor and the use of pesticides. Revista Brasileira de Enfermagen [Internet]. 2016; 69 (6): 1114-22.

13. Bureau UC. Urban and rural [Internet]. United State Department of Commerce. 2016 [cited 2017 Aug 4]. Available from: https://www.census.gov/geo/reference/urban-rural.html

14. Aditya I. Purworejo Sentra Bibit Tanaman Terbesar Nasional Kedaulatan Rakyat Online Yogyakarta [Internet]. Kedaulatan Rakyat. 2015 [cited 2016 Jan 25]. Available from: http://img.krjogja.com/ $\mathrm{read} / 248199$

15. Sapbamrer R, Nata S. Health symptoms related to pesticide exposure and agricultural tasks among rice farmers from northern Thailand. Environmental Health Preventive Medicine. 2014; 19: 12-20.

16. Wright JM, Keller-byrne J. Environmental determinants of parkinson's disease. Archives of Environmental \& Occupational Health. 2005; 60 (1): 37-41.

17. Kesavachandran C, Pathak MK, Fareed M, Bihari V, Mathur N, Srivastava AK. Health risks of employees working in pesticide retail shops: An exploratory study. Indian Journal of Occupational and Environmental Medicine. 2009; 13 (3): 121-6.

18. Elbaz A, Moisan F. The scientific bases to consider Parkinson's disease an occupational disease in agriculture profesionals exposed to pesticides in France. Journal of Epidemiology and Community Health. 2016; 70 (4): 319-21.

19. Engel LS. Parkinsonism and pesticide exposure among rural residents of Washington State. Ann Arbor: University of Washington; 1999.

20. Lekei EE, Ngowi A V, London L. Pesticide retailers' knowledge and 
handling practices in selected towns of Tanzania. Environmental Health [Internet]. 2014; 13(1): 79. Available from: http://www.ehjournal.net/ content/13/1/79

21. Fareed M, Pathak MK, Bihari V, Kamal R, Srivastava AK, Kesavachandran $\mathrm{CN}$. Adverse respiratory health and hematological alterations among agricultural workers occupationally exposed to organophosphate pesticides: A cross-sectional study in North India. PLoS One. 2013; 8 (7): 1-10.

22. Pathak MK, Fareed M, Srivastava AK, Pangtey BS, Bihari V, Kuddus M, et al. Seasonal variations in cholinesterase activity, nerve conduction ve- locity and lung function among sprayers exposed to mixture of pesticides. Environmental Science and Pollution Study [Internet]. 2013; 20(10): 7296-300. Available from: http://link.springer.

23. LaVerda N. Pesticide exposures and Body-Mass-Index (BMI ) in a cohort of male pesticide applicators. Ann Arbor: The George Washington University; 2013.

24. Sekiyama M, Tanaka M, Gunawan B, Abdoellah O, Watanabe C. Pesticide usage and its association with health symptoms among farmers in rural villages in west Java, Indonesia. Environmental Science. 2007; 14: S23-S33. 